\title{
Entrepreneurial Intellectual Capital [Human Capital, Social Capital, Customer Capital, Technology Capital] on SME's performance in Medan, Indonesia
}

\author{
Yasmin Chairunisa Muchtar \\ Department of Management \\ University of Sumatera Utara \\ Medan, Indonesia
}

\author{
Inneke Qamariah \\ Department of Management \\ University of Sumatera Utara \\ Medan, Indonesia
}

\begin{abstract}
This study aims to investigate the effect of Entrepreneurial Intellectual Capital [Human Capital, Social Capital, Customer Capital, Technology Capital] on SME's performance in Medan, Indonesia. Sixty business owners from various sector are used as samples in this survey. Data analysis used in this study is multiple linear regression. This multiple regression analysis indicates that Entrepreneurial Intellectual Capital has significant and positive effects on SME's performance.
\end{abstract}

Keywords-Entrepreneurial Intellectual Capital; Human Capital; Social Capital; Customer Capital; Technological Capital; SME's Performance

\section{INTRODUCTION}

Small and medium enterprises [SMEs] have become the driving force for economic growth in many developing countries. SMEs also provide employments, national income sources and play a major role in supporting technology-based innovation. SMEs in Indonesia has a very big role in encouraging the economic sector. However, there are some issues concerning SMEs that must be addressed for the further development of SMEs. One way that can be done is to utilize intellectual capital to drive the performance of SMEs.

Intellectual capital is an important factor, a strategic asset that determines the success of an organization. Especially, in a competitive environment, intellectual capital becomes increasingly important. In the industrial era, traditional assets such as land and capital and tangible assets are very important sources of production. But along with the transformation of industrial era into the era of knowledge-based economy, the understanding of assets also changed. Intellectual capital can be expressed as the backbone of a information-based economy. Intellectual capital can also be expressed as a management strategy utilized for the organization to generate profit and achieve desired performance [1]

Research on intellectual capital has been undertaken by some earlier researchers in developing countries such as Indonesia, Malaysia and Pakistan [1], [2]; [3]. But the numbers of research done in Indonesia are still very little and the concept of intellectual capital still is new for SMEs in
Indonesia. Therefore, researchers are interested to conduct research on this topic in order to be able to contribute to the development of SMEs in Indonesia.

This study aims to analyze the effects of Entrepreneurial Intellectual Capital [Human Capital, Social Capital, Customer Capital, Technological Capital] on SMEs performance.

\section{LITERATURE REVIEW AND HYPOTHESIS}

\section{A. Entrepreneurship}

Entrepreneurship is defined as the process of value creation by utilizing a unique available resources to create opportunities [4]. Entrepreneurship can also be explained as an entrepreneurial orientation that demonstrates three dimensions of innovation, pro-activeness and taking calculated risks [4]. Entrepreneurship is the process of creating something new at the value of utilizing time and effort, taking on the financial, physical and social risks, receiving generated monetary rewards, as well as personal satisfaction and freedom [5].

Entrepreneurs perform a process called creative destruction to produce a higher value. Therefore, creativity is the core of entrepreneurial skills.

\section{B. Intellectual Capital in Entrepreneurship}

Intellectual Capital differentiate between the market value of the firm and the book value of the company's assets or its financial capital. Intellectual Capital by [6] refers to the knowledge and abilities possessed by a social collective, such as an organization, an intellectual community, or professional practice. Intellectual capital represents valuable resources and the ability to act based on knowledge.[7] proposed the Integrated Intellectual Capital Model [IICM] which is based on six major components of intellectual capital, namely, human capital, customer capital, structural capital, social capital, technological capital and spiritual capital. Intellectual Capital [IC] had met the pre-requirements of unique resources which became competitive advantages composing the values of the company [8]. 


\section{1) Human Capital}

Human capital is a major component of intellectual capital based on employees' set of knowledge, skills, experience, and abilities that can generate value for the organization. [9]; [10]; and [11]

Human capital can generally be expressed as an essential component of intellectual capital based on:

a. Competencies such as education, professional skills, knowledge

b. Attitude such as motivation, leadership, behavior patterns

c. Intellectual agility such as innovation, creativity, flexibility, adaptability [12];[13]; [14].

2) Social Capital

Coleman in Fukuyama [15] stated that Social Capital is a human ability to work together to achieve common goals in various groups and organizations. The theory of social capital states that the relationship network is a resource that can be implemented in daily activities. Members of the "capital" network can be utilize for various purposes such as access, information, availability, opportunities and social status.

Social capital is a resource with core elements that include:

a. Trust: The tendency to fulfill what has been said or written. The existence of this nature of trust is the main basis for a person to surrender something to others, with the belief that the person will keep his promise or obligation. This includes honesty, fairness, tolerance, and generosity,

b. The social network includes participation, reciprocity, and solidarity. It is the willingness to share a consequence as a form of a sense of togetherness in the face of a problem, collaboration, and equity,

c. Norms consist of understandings, values, expectations, and goals that are believed and executed by a group of people. The norms come from professional ethics. Norms are built and grown based on the history of cooperation in the past and applied to support the cooperative climate. Norms can be defined as preconditions and products of social trust.

[11] and [16] argue that social capital is one of the most important components in intellectual capital, which has a significant contribution to organizational performance.

\section{3) Customer Capital}

Customer capital is based on the relationship between the organization and the customer [17]; [18]; [19].

Customer capital consists of brand value, strong network with customers, customer loyalty, and customer satisfaction. It has a positive relationship to organizational performance [20], [21]

\section{4) Technology Capital}

Technological capital is also one of the vital components in intellectual capital consisting of a set of intangible assets based on innovation and technical processes. [11] and [22]; and [23].

\section{SME's Performance}

Organizational performance is a measure of the success of a company in achieving its objectives. Measures of organizational performance can be both quantitative and qualitative. Quantitative measurements are done in the form of financial achievements [ROE, ROA, ROI], production [number of goods sold, operational cost ratio], marketing [number of customers], and efficiency. Qualitative measurements are done in the form of discipline, the quality of achievement of goals, the perceptions of leadership on organizational outcomes, individual behavior in the organization, and effectiveness [24].

This is also supported by [25], which states that business performance can be classified in 2 aspects, namely the quantitative aspect which is the financial aspect and qualitative aspect which is non-financial aspect [26]. Financial aspects include the level of sales, finance, profitability, productivity, product value added and market share [27]; [28]. The non-financial aspect include consumer's satisfaction, human resource development and employee working satisfaction [29];[27].

[30] classifies several performance measures for small and medium enterprises: First, performance measurements are based on the balanced scorecard and consists of internal business processes, financial innovations and learning and consumers. Second, performance measurements based on Kaiser-Meyer-Olkin [KMO] consists of strategy, productivity, finance, innovation, employee learning, and satisfaction. Third, performance measurements based on performance measurement system consists of finance, quality, employee, innovation, and consumer.

\section{Hypothesis}

Based on the description above, the hypothesis can be stated as follows:

H1: Entrepreneurial Intellectual Capital in entrepreneurship positively and significantly effects SME's performance.

H2: Human capital positively and significantly effects SME's performance.

H3: Social capital positively and significantly effects SME's performance.

H4: Customer capital positively and significantly effects SME's performance.

H5: Technology capital positively and significantly effects SME's performance.

\section{E. Focus of This Study}

Intellectual capital is a key to a successful business competition. These consist of expertise possessed by workers, machinery, equipment potential, ability to increase customer value, ability to build customer relationships with suppliers, and ability to benefit society. With the intellectual capital, SMEs will be able to create and develop new ideas, implement technological innovation and certainly able to improve 
performance in order to compete so that SMEs, the motor of the nation's economy, will work well.

\section{METHODOLOGY}

\section{A. Sample and Data Collection}

The population in this study are all SMEs in Medan city with the criteria:

1. SME with legal entity.

2. Small and Medium Enterprises [SMEs] owned by all members of Regional Board of Association of Young Entrepreneurs Indonesia [BPD HIPMI] North Sumatera period 2014-2017.

3. Members of the Chamber of Commerce and Industry [KADIN] of North Sumatra. In total there are 60 business owners.

In this study, all members of the population are sampled for the study. Therefore, the samples for this research are 60 business actors engaged in various business fields.

\section{B. Measures}

All construct is measured using five-point Likert scales ranging from $1=$ strongly disagree to $5=$ strongly agree. This scale consists of 7 dimensions, namely pro-activeness [8 items], calculated risk-taking [8 items], innovativeness [8 items], opportunity focus [8 items], resource leveraging [9 items], customer intensity [9 items] and value creation [6 items]. To measure competitive advantage, this research is using five-point Likert Scales ranging 1=strongly disagree to $5=$ strongly agree.

In this study, questionnaire for performance appraisal using a subjective scale, that is the perception of the manager or owner of the industry

Data collection in this study was conducted by using two techniques:

1. In-depth interviews with the perpetrators of SMEs in Medan to obtain data or information required.

2. Questionnaires.

This study uses descriptive statistics methods To provide an overview of the respondent's demographics [gender, term of office, level of education, length of work] and description of research variables. The researcher uses frequency distribution table that shows the value of the distribution of research data that has the same category by using the absolute frequency distribution table showing the maximum number, the minimum number, the average, and the standard deviation.

This study uses Multiple Linear Regression Analysis with the help of SPSS program. This test is conducted to analyze the effect of Intellectual Capital in entrepreneurship [Human Capital, Social Capital, Customer Capital, Technology Capital] on the performance of SMEs.

\section{Analysis and Results}

Model Summary

\begin{tabular}{|c|c|c|c|c|}
\hline Model & $\mathrm{R}$ & R Square & $\begin{array}{l}\text { Adjusted R } \\
\text { Square }\end{array}$ & $\begin{array}{l}\text { Std. Error of the } \\
\text { Estimate }\end{array}$ \\
\hline 1 & $.677^{\mathrm{a}}$ & .458 & .419 & 2.401 \\
\hline
\end{tabular}

a. Predictors: [Constant], technology capital, human capital, social capital, customer capital

1. R-value $=0.677$ meaning human capital, social capital, customer capital, and technology capital have a close relationship with business performance

2. Adjusted R Square $=0.419$ meaning $41.9 \%$ of business performance can be explained by human capital, social capital, customer capital and technology capital. While the remaining $58.1 \%$ can be explained by other factors that are not examined in this study.

ANOVA $^{\mathrm{a}}$

\begin{tabular}{|ll|r|r|r|c|c|}
\hline & Model & Sum of Squares & df & Mean Square & F & Sig. \\
\hline 1 & Regression & 268.233 & 4 & 67.058 & 11.631 & $.000^{\mathrm{b}}$ \\
& Residual & 317.101 & 55 & 5.765 & & \\
Total & 585.333 & 59 & & & \\
\hline
\end{tabular}

a. Dependent Variable: Performance

b. Predictors: [Constant], technology capital, human capital, social capital, customer capital

The table shoes that the F-count $=11.631$ with a significant level of 0.000 . If F-count $>$ F-table and its significance level $[0.000]<0.05$, it indicates that the effect of independent variables [human capital, social capital, customer capital and technology capital] simultaneously is significant towards SMEs performance in Medan.

\begin{tabular}{|c|c|c|c|c|c|}
\hline \multicolumn{6}{|c|}{ Coefficients $^{\mathrm{a}}$} \\
\hline \multirow[b]{2}{*}{ Model } & \multicolumn{2}{|c|}{$\begin{array}{l}\text { Unstandardized } \\
\text { Coefficients }\end{array}$} & \multirow{2}{*}{$\begin{array}{c}\text { Standardized } \\
\text { Coefficients } \\
\text { Beta }\end{array}$} & \multirow[b]{2}{*}{$\mathrm{T}$} & \multirow[b]{2}{*}{ Sig. } \\
\hline & B & $\begin{array}{l}\text { Std. } \\
\text { Error }\end{array}$ & & & \\
\hline 1 [Constant] & -7.539 & 8.050 & & -.936 & .353 \\
\hline Human capital & .140 & .162 & .091 & .863 & .392 \\
\hline Social capital & .329 & .146 & .250 & 2.246 & .029 \\
\hline Customer capital & .295 & .106 & .339 & 2.787 & .007 \\
\hline Technology capital & .401 & .183 & .250 & 2.197 & .032 \\
\hline
\end{tabular}

1. Human capital affects business performance positively and insignificantly. Significant value [0.392] $>0.05$ and t-count $[0.863]<$ t-table.

2. Social capital affects business performance positively and significantly. Significant value $0.029<0.05$ and $t-$ count $[2.246]<$ t-table.

3. Customer capital affects business performance positively and significantly. Significant value [0.007] $<0.05$ and t-count [2.787] > t-table.

4. Technological capital affects business performance positively and significantly. Significant value $[0.032<$ 0.05 and t-count [2.197] < t-table.

\section{CONCLUSION AND LiMITATIONS}

Based on the results of the analysis and discussion done in this study, the conclusions are:

1. Human capital on performance. 
Human capital is a major component of intellectual capital based on a set of knowledge, skills, experience, and abilities of workers that can generate value for the organization. [10]; [11]; and [12].

The results of T-test on human capital partially indicates positive and insignificant effect on business performance. It shows that the human capital can help improve business performance the factor that can creates the improvement itself.

Human capital become because in starting a business, the very foremost important things to have is the characters of the entrepreneur itself. These characters; leadership, talent, courage, and integrity are the key to success and to increase its competence, these traits must be added to human capital

2. Social capital on performance.

Coleman in Fukuyama [16] states that social Capital is the ability to work together to achieve common goals in various groups and organizations. The theory of social capital states that the relationship network is a resource implemented in daily activities. The "capital" networks can be access, information, availability, opportunities, and social status. [11] and [17] argue that social capital is one of the most important components in intellectual capital, which contributes significantly to organizational performance.

Based on the result of t-test on social capital, it shows positive and significant influence to business performance. It shows that social capital influence business performance through network utilization and to create and increase corporate network growth

\section{Customer capital on performance}

Customer capital consist of external relationships with customers, suppliers or partners in Research and Development [R \& D] [31], including brand, consumer, consumer name loyalty, distribution network, business collaboration, licensing agreements and supportive contracts. Good customer capital management leads the development of organizational activity or response to market changes. If an organization focus on customers and becomes a market maker, it will create efficient organizational routines and processes that can serve customers well.

Customer capital is basically based on the relationship between the organization and the customer [18]; [19]; and [20]. Customer capital consists of brand value, strong network with customers, customer loyalty, customer satisfaction that has a positive relationship to organizational performance [21]; [22].

T-test on customer capital shows positive and significant influence on business performance. It proves that customer's capital is important as it is influential in improving business performance by helping the company to market its product and services

\section{Technology capital on performance}

[32] argues that technology provides a positive value for management strategies related to the aspects of communication, information access, decision making, data management and knowledge management in an organization. Technology can become a strategic strength and tools for organizations that benefit the promotional activity and obtain competitiveness [33].

T-test on technological capital shows a positive and significant influence on business performance. It shows that technology can significantly improve business performance through utilization of technology and innovation aimed at efficiency of production process, efficiency cost, and innovation in the marketing of products and services.

Good resources supported by good technology will produce good output and quality. Technology provides benefits for business organizations to reduce costs and improve the ability of business organizations to coordinate with outsiders. Technology has also been shown to have a positive impact on organizational performance [34]. That's why technology capital is needed to improve the performance of SMEs as technology also provides convenience in promoting the product

\section{REFERENCES}

[1] Khalique M and Md. Isa. A.H, (2014),Intellectual Capital in SMEs Operating in Boutique Sector in Kuching,Malaysia, The IUP Journal of Management Research, Vol. XIII,No. 2.

[2] Supeno. H., Sudharma. M., Aisyah.S and Laksamana. A,(2015) The Effect of Inttelectual Capital,Strategic Flexibility,and Micro-Scaled Enteprises (SMEs) in Gerbangkertosusila Region,East Java, International Business and Management, Vol 11,No.1.

[3] Khalique M., Md Isa. A.H, and Shaari. J.A.N (2013), Predicting the Impact of Inttelectual Capital Management on the Performance of SMEs in Electronics Industry in Kuching,Sarawal, The IUP Journal of Knowledge Management, Vol. XI, No.4

[4] Morris, M,H., Schindehutte, M., and La Forge, R, W., (2002), Entrepreneurial Marketing : A Construct For Integrating Emerging Entrepreneurship and Marketing Perspectives, Vol 10, No.4, page 1-19

[5] Hisrich, R.D., Peters, M.P., dan Shepherd D.A. (2008). Kewirausahaan Edisi 7. Edisi Bahasa Indonesia. Jakarta: Salemba Empat

[6] Nahapiet, J. And Ghosal, S. (1998), "Social capital intellectual capital and the organizational advantage", Academy of Management Review, Vol.23 No. 2, pp. 242-266.

[7] Khalique M, Shaari J A N and Isa A H B M (2011), "Intellectual Capital and Its Major components", International Journal of Current Research, Vol. 3, No. 6, pp. 343-347.

[8] Barney , J . (1991). Firm Resources and Sustaned Competitive Advantage. Journal of Management, 17 (1), 99-120

[9] Bontis, N., Keow, W., \& Richardson, S. (2000). Intellectual capital of business performance in Malaysia industries. Journal of Intellectual Capital, 1(1), 85-100

[10] Bueno E, Salmador M P and Rodriguez O (2004), The Role of Social Capital in Today's Economy: Empirical Evidence and Proposal of a 
New Model of Intellectual Capital", Journal of Intellectual Capital, Vol. 5, No. 4, pp. 556-574

[11] Khalique M (2012), Impact of Intellectual Capital on the Organizational Performance of Selected Small and Medium Enterprises in Malaysia and Pakistan,Ph.D. Thesis, Universiti Malaysia Sarawak.

[12] Bontis, N. (1998), "Intellectual capital: an exploratory study that develops measures and models", Management Decision, Vol. 36 No 2, pp. 63-76.

[13] Bontis,N., Dragonetti,N.C., Jacobsen,K and Roos ,G. (1999), The Knowledge toolbox: a review of the tools available to measure and manage intangible resources, European Management Journal,Vol.17 No.4 pp.391-402

[14] Tovstiga, G. And Tulugurova, E. (2007), “ Intellectual Capital practices and performance in Russian entreprises", Journal of Intellectual Capital, Vol. 8 No.4 pp. 695-707.

[15] Fukuyuma F (2002), Social Capital and Development: The Coming Agenda, "SAIS Reviewe 22 (1) : 23-37.

[16] Hamzah Noradiva and mat Isa Rosmah (2011), "Intellectual and Social Capitals

[17] Edvinsson L and Malone M (1997), Intellectual Capital, Harper Business, New York. Development: A Case in Malaysian's ICT Companies", International Journal of Business and Management, Vol. 5, No.1.

[18] Tai-Ning Y, Hsiao-Chen C, Shou-Yen L and Chiao-Lun T (2011), "Knowledge Creation and Intellectual Capital on Securities Investment Services", African Journal of Business management, Vol. 5, No. 3, pp 924-933.

[19] Khalique M, Isa A H B M and Shari J A N B (2013), "Predicting the Impact of Intellectual Capital Management on the Performance of SMEs in Electronics Industry in Kuching, Sarawak" the IUP Journal of Knowledge Management, Vol. 11, No. 4, pp. 53-61.

[20] Ismail M B (2005), "The influence of Intellectual Capital on the Performance of Telekom Malaysia", Ph.D. Thesis, Universiti Teknologi Malaysia.

[21] Kim, D.Y. and Kumar, V. (2009), "A framework for prioritization of intellectual capital indicators in R\&D”, Journal of intellectual Capital, Vol. 10 No. 2, pp. 277-293

[22] Bueneo E, Salmador M P, Rodriguez O and De Castro G M (2006), Internal Logic of Inttelectual Capital: A Biological Approach. Journal of Intellectual Capital, Vol. 7,No. 3, pp.394-405.

[23] Wu W Y and Tsai H J (2005), "Impact of Social Capital and Business Operation Mode on Intellectual Capital and Knowledge management", International Journal of Technology Management, Vol. 30, No. 1, pp. 147-171.

[24] Ratno Purnomo, and Sri Lestari (2010). Jurnal Bisnis dan Ekonomi (JBE); Hal 144-160 Vol. 17, No.2. ISSN : 1412-3126.

[25] Ismail, A.I., Rose, R.C., Abdullah, H., Uli, J. (2010) The Relationship Between Organisational Competitive Advantage and Performance Moderaed by the Age and Size of Firms", Asian Academy of Management Journal, Vol.15, Nr.2,pp.157-173

[26] Neely, A. (2005). The Evolution of performance measurement research. Developments in the last decade and research agenda for the next. International Journal of Operations \& Production Management. Vol 25 No 12, page 1264-1277

[27] Falshaw, J.R., Glaister, K.W. and Ekrem, T. (2006). "Evidence on Formal Strategic Planning and Company Performance. Management Decision", 44(1), pp. 9-30.

[28] Wang, Y. and Lo, H. (2003). "Customer-focused Performance and the Dynamic Model for Competence Building and Leveraging: A Resourcebased View", Journal of Management Development, 22(6), pp. 483-526.

[29] Sousa, S.D., Aspinwal, E.M., and Rodrigues, A.G, 2006, Performance measures in English Small Medium Entreprises: Survey Results. Bencmarking: An International Journal, 13, 120-134.

[30] Starovic. D. And Marr B (2003), Understanding Corporate Value : Managing and Reporting Intellectual Capital, The Chartered Institute of Management Accountants (CIMA) London.

[31] Adeousun, O.O., Adeosun, T.H., \& Adetunde, I.A. (2009). Strategic Application of Information and Communication Technology for
Effective Service delivery in Banking Industry Journal of Social Sciences, 5(1), 47-51.

[32] Buhalis.D (2003). e Tourism : Information technology for Strategic Tourism Management, Prentice Hall, London.

[33] Maldeni, H.M.C.M and Jayasena, S (2009). Information and Communication Techlogy Usage and Bank Branch Performance. The International Journal on Advances in ICT for Emerging Regions, 2 (2) : 29-37. 